\title{
REVIEW EFEKTIFITAS MODEL COOPERATIVE LEARNING DALAM PEMBELAJARAN BAHASA
}

\author{
Samsu Armadi \\ Universitas Kutai Kartanegara \\ Jl. Gunung Kombeng No. 27 Tenggarong, Kutai Kartanegara
}

\begin{abstract}
Cooperative learning has been implemented widely in teaching learning process resulting optimum outcomes in learning. Five principles of learning in the cooperative learning are essential, making cooperative learning efficient and different from just placing students into groups. This paper is a review of cooperative learning for language class. However, the evidence indicates that cooperative learning is also applicable for lessons other than language class.
\end{abstract}

Keywords: cooperative learning, group, language class.

Pembelajaran kooperatif merupakan suatu konsep dimana siswa belajar dalam kelompok-kelompok kecil yang memiliki tingkat kemampuan berbeda. Dalam menyelesaikan tugas kelompok, setiap anggota saling bekerja sama dan membantu untuk memahami suatu bahan pembelajaran. Belajar belum selesai jika salah satu teman dalam kelompok belum menguasai bahan pembelajaran (Elok, 2001).

Model pembelajaran kooperatif dikembangkan untuk mencapai setidaktidaknya tiga tujuan pembelajaran penting, yaitu hasil belajar akademik, penerimaan terhadap keragaman, dan pengembangan keterampilan sosial. Beberapa ahli berpendapat bahwa model ini unggul dalam membantu siswa memahami konsep yang sulit, dan sangat berguna untuk membantu siswa menumbuhkan kemampuan bekerja sama dan kolaborasi (Maaruf, 2003).

Menurut Kauchak dan Eggan (1996:277) pembelajaran kooperatif merupakan strategi pembelajaran yang melibatkan siswa untuk bekerja secara partisipatif dan koloboratif dalam mencapai tujuan. Sedangkan Slavin (1994:287) mengatakan bahwa dalam pembelajaran kooperatif siswa bekerja sama dalam kelompok kecil saling membantu untuk mempelajari suatu materi.

Karakteristik pembelajaran kooperatif yakni, (a) anggota bekerja dalam kelompok kooperatif untuk menguasai materi akademik, (b) anggota kelompok di atur terdiri dari berkemampuan tinggi, sedang, dan rendah, (c) jika mungkin, masing-masing anggota kelompok kooperatif berbeda suku, budaya dan jenis kelamin, dan (d) sistem penghargaan lebih berorentasi pada kelompok dari pada individu (Arends, 1997:111) Dengan memperhatikan beberapa 
keragaman dalam suatu kelompok diharapkan muncul sikap partisipatif dan koloboratif dalam menyelesaikan masalah yang diberikan.

Pembelajaran kooperatif mempunyai tiga tujuan, yakni prestasi akademik, penerimaan keanekaragaman,dan pengembangan ketrampilan sosial (Arends, 1997:111). Diharapkan melalui kelompok yang kooperatif, ratarata prestasi akademik mahasiswa dapat terangkat, karena mahasiswa yang berprestasi rendah dan tinggi secara bersama-sama menangai tugas akademik yang dibebankan melalui tutor teman sebaya. Pembelajaran kooperatif menyajikan peluang bagi mahasiswa dari berbagai latar belakang dan kondisi, untuk bekerja dalam kondisi saling ketergantungan yang positif dalam menangani tugas akademis. Dari aspek keterampilan sosial, pembelajaran kooperatif mampu membentuk sikap bekerjasama.

Pembelajaran Kooperatif (PK) sesungguhnya sudah ada sejak zaman dulu. Zaman itu, guru mangarahkan siswa untuk bekerja bersama dalam bentuk proyek tertentu, dalam diskusi kelompok atau debat, atau dalam bentuk kelompok lain, seperti praktik tutorial. Metode ini secara umum bersifat informal, tidak terencana, dan hanya digunakan untuk hal-hal tertentu.

Namun, 20 tahun yang lalu, terjadi perkembangan yang signifikans. Pertama kali, strategi belajar menggunakan teknik PK dirumuskan dan dievaluasi dalam berbagai konteks pengajaran. Atas jerih payah penelitian yang dilakukan terhadap ribuan guru yang mengajar menggukan PK, saat ini metode PK yang lebih efektif bisa dikemukakan sesuai dengan tujuan pembelajaran yang juga beraneka ragam. Karena itu, saat ini guru bisa memilih teknik PK yang paling cocok sesuai dengan tujuan pembelajarannya, dan menggunakan PK sebagai metode utama pengajara di kelas, dan bukan semata-mata hanya metode selingan yang digunakan sewaktu-waktu saja.

Beberapa hasil penelitian di bidang PK telah menunjukkan kemajuan yang signifikans bagi efektifitas PK. Inti dari hasil penelitian tersebut mengemukakan bahwa PK bisa digunakan secara lebih efektif karena beberapa alasan. Pertama, PK sesuai dengan kondisi pembelajaran di kelas yang menuntut agar siswa lebih aktif dan tidak semata-mata duduk diam mendengarkan penjelasan guru. Untuk mengatasi siswa yang diam tersebut, PK bisa digunakan sebagai sarana mendorong, memotivasi dan menciptakan kreativitas sampai siswa bisa bekerja sendiri. Kedua, siswa yang memliki kemampuan kurang, umumnya akan cepat menyerah apabila mereka mengerjakan tugas sendirian. Melalui PK, siswa tersebut akan mendapat partner dan bisa bekerjasama untuk memecahkan masalah. Ketiga, siswa yang cerdas dan bekerja cepat, biasanya akan merasa cepat bosan. Melalui PK, siswa tersebut bisa berkesempatan memberikan penjelasan kepada siswa yang kurang. Keempat, siswa bisa bekerja secara kompetitif, bersaing dengan anggita kelompok lainnya sehingga mereka terdorong untuk bekerja lebih baik dan lebih cepat. 
Namun demikian, PK juga memberikan persoalan bagi guru. Guru yang sabar dan berpengalaman, bisa memanfaatkan kondisi ini dengan baik. Sebaliknya guru yang kurang sabar dan kurang berpengalaman, akan menjadi frustrasi menghadapi keadaan ini. Umumnya, siswa yang pandai akan mengklaim tidak enak bekerja sama dengan siswa lain yang kurang pandai. Karena itu, siswa pandai tersebut lebih banyak bertanya dan minta perhatian guru. Sebaliknya, siswa yang kurang pandai juga komplain ke guru karena kurang diperhatikan. Guru yang memiliki pengalaman cukup akan bisa mengkombinasikan situasi ini sehingga situasi kelas dalam kontrol PK bisa berjalan dengan baik.

\section{HAKIKAT PEMBELAJARAN KOOPERATIF}

PK merupakan model pembelajaran yang melibatkan siswa bekerja dalam tim untuk mencapai tujuan umum pembelajaran. Berbagai studi mengenai PK menunjukkan bahwa PK memiliki keunggulan dalam pengajaran bahasa. Hakikatnya, PK merupakan jawaban terhadap tiga jenis model pengelolaan kelas yang sejauh ini dilaksanakan.

Contextual Teaching and Learning (CTL) merupakan konsep belajar yang membantu guru mengaitkan antara materi yang diajarkannya dengan situasi dunia nyata siswa dan mendorong siswa membuat hubungan antara pengetahuan yang dimilikinya dengan penerapannya dalam kehidupan mereka sehari-hari, dengan melibatkan tujuh komponen utama pembelajaran efektif, yakni: konstruktivisme, bertanya, me-nemukan, masyarakat belajar, pemodelan, refleksi, dan penilaian sebenarnya (Depdiknas, 2002:5).

Menurut Berns (2001), CL (Cooperative Learning) merupakan salah satu prinsip CTL yaitu menciptakan 'masyarakat belajar' (belajar dalam kelompokkelompok). Pembelajaran dilaksanakan dengan cara mengelompokkan siswa. CTL merupakan suatu pendekatan yang ditawarkan dalam menerapkan kurikulum ber-basis kompetensi. Hal yang sama dinyatakan juga oleh Alwi (2004).

Dikatakan oleh Lie (2002:3) dalam CTL, para siswa disarankan selalu melaksanakan pembelajaran dalam kelompok-kelompok belajar. Siswa dibagi dalam kelompok-kelompok yang anggotanya heterogen. Yang pandai mengajari yang lemah, yang tahu memberi tahu yang belum tahu, yang cepat menangkap mendorong temannya yang lambat, yang mempunyai gagasan segera memberi usul, dan seterusnya. Kelompok siswa bisa ber-variasi bentuknya, baik keanggotaan maupun jumlahnya. Dapat melibatkan siswa di kelas lain atau guru secra berkolaborasi mendatangkan 'ahli' ke kelas.

Bentuk CL sangat variatif, salah satunya 'kancing gemerincing' dan 'berpasangan bertukar salam'. Cara 'gancing gemerincing' dilakukan dengan memberi kancing kepada setiap anggota kelompok, dengan jumlah yang sama. Setiap berbicara mengeluarkan satu kancing. Peserta yang kancingnya sudah habis tidak berhak lagi berbicara sampai semua peserta tidak ada lagi yang 
memiliki kancing. Dengan cara berpasangan berkirim salam, setiap peserta dalam kelompok pertama dikirim/pindah ke kelompok lain membawa soal dari kelompoknya untuk dijawab/didiskusikan di kelompok baru. Dua cara ini dilakukan untuk menghindari adanya dominasi oleh seseorang dan atau menghindari adanya siswa yang pasif.

$\mathrm{CL}$ bisa terjadi bila ada komunikasi multiarah. Seorang guru mengajari siswa bukan contoh masyarakat belajar karena komunikasi hanya terjadi satu arah, yaitu informasi dari guru kepada siswa, tidak ada arus informasi yang perlu dipelajari guru dari siswa. Dalam hal ini yang belajar hanya siswa bukan guru. Dinyatakan dalam Depdiknas (2002:15) bahwa dalam masyarakat belajar, seseorang yang terlibat dalam kegiatan CL memberi informasi yang diperlukan oleh beberapa teman bicaranya dan sekaligus juga meminta informasi yang diperlukan dari teman belajarnya.

Malalui CL siswa akan berlatih produktif, mereka akan saling 'memberi', saling 'isi', dan bertanggung jawab terhadap setiap anggota kelompoknya, dan dalam menyelesaikan tugas-tugas yang diberikan guru. Dengan CL diharapkan tidak ada lagi siswa yang takut, yang malu-malu, atau pasif, mereka harus aktif dalam kelompok karena setiap kelompok akan memajang/menampilkan hasil kerjanya di kelas dan akan dinilai oleh guru dan kelompok/siswa lain. Hal ini sudah dibuktikan juga oleh Alwi (2005).

Penilaian otentik digunakan untuk mendeskripsikan berbagai bentuk penilian yang merefleksikan proses pembelajaran yang dialami siswa, kemampuan, motivasi, dan sikap siswa yang sesuai dengan hasil belajar yang diharapkan. Menurut Ibrahim (2003:1) penilaian otentik mencakup hasil belajar siswa secara komprehensif. Pentingnya penilaian otentik menurut Bernas (2001) harus dapat memberikan informasi yang utuh tentang sosok siswa yang dinilai agar keputusan yang dibuat tidak bias.

Dalam pembelajaran bahasa, penilaian secara otentik mengacu pada penilaian tugas-tugas berbahasa yang sesuai dengan konteks pebelajar sebagai siswa, anggata masyrakat, anggota keluarga, dan calon pekerja (Titik, 2003). Adapun tujuan penilaian, dikatakan oleh Johnson (2002:149), untuk menilai berbagai kemampuan berbahasa siswa dalam berbagai konteks yang dialami siswa. Materi pembelajaran dan penilaian-nya diupayakan sealamiah mungkin. Penilaian juga mencakup proses yang terjadi dan penyelesaian sebuah karya.

Dikatakan juga oleh Nurhadi (2002:1), dengan menerapkan penilaian otentik diharapkan proses dan hasil pembelajaran keterampilan bahasa menjadi meningkat, siswa senang belajar bahasa karena mereka dapat mengetahui perkembangan kemampuan mereka tidak hanya dari guru, tetapi juga dari teman, dan dari diri sendiri. Adapun alat penilaian yang dapat digunakan, menurut Nurhadi (2002:2-3) adalah sebagai berikut:

1) portofolio, berupa kumpulan karya tulis siswa selama satu semester/tahun. 
2) karya tulis siswa: laporan perjalanan, puisi, artikel, essei, cerpen, karya ilmiah populer, dsb;

1) penampilan siswa dalam berbicara, berwawancara, dan berdiskusi;

2) tes tulis akhir semester;

3) hasil pengamatan guru;

4) lembar kegiatan siswa, berupa lembar kerja siswa;

5) drama, simulasi, bermian peran, dan sebagainya.

Terkait dengan PK, ada tiga asumsi pengelolaan kelas yang kemudian bisa dikombinasikan untuk memperoleh hasil belajar yang efektif. Pertama, kelas bersifat kompetitif. Dalam kelas yang kompetitif ini, siswa diarahkan agar bersaing dengan temannya. Akibatnya, teman sekelas akan dianggap sebagai musuh dan karena itu tidak bisa bekerja sama. Kedua, kelas bersifat individualistik. Dalam konteks ini, hasil kerja siswa yang terpenting ialah kerja mandiri dan dikerjakan sendiri. Kemampuan kelompok bukanlah jerih payah sendiri karena itu unsur terpenting dalam kelas ialah siswa bekerja secara individu. Ketiga, kelas bersifat kooperatif. Model ini menekankan bahwa kelas merupakan wadah belajar bersama karena itu, anggota kelas harus saling membantu dan bekerjasama. Saling membantu dimaksud meliputi membantu memecahkan masalah, memberikan pengertian, dan menyelesaikan tugastugas kelas dalam kebersamaan yang saling menguntungkan.

Namun, PK bukanlah sekadar mengelompokkan siswa dalam suatu grup. Tujuan PK ialah mengelompokkan siswa dalam suatu grup untuk mencapai tujuan pembelajaran. Karena itu, PK hanya bisa dicapai apabila beberapa syarat terpenuhi. Johnson, Johnson, dan Smith (1991) mengemukakan, untuk mencapai tujuan umum tersebut, ada lima hal yang harus dicapai. Kelima hal tersebut ialah:

1. Saling ketergantungan positif.

Setiap anggota tim harus saling percaya satu sama lain dan saling bekerjasama untuk mencapai tujuan. Jika salah satu anggota tim tidak bisa bekerja sama, anggota yang lain terancam gagal mencapai tujuan.

2. Akuntabilitas individu.

Seluruh siswa dalam kelompok bertanggungjawab untuk saling membantu dalam bekerja dan berbagi pengetahuan dan penguasaan materi yang sedang dipelajari secara bersama-sama.

3. Interaksi sinergis secara empat mata.

Walaupun sebagian anggota kelompok ada yang bekerja secara individu, anggota yang lain bertanggungjawab untuk saling interaksi dan tatap muka dengan anggota yang lainnya lagi. Interaksi ini harus memberikan umpanbalik, memberikan simpulan, alasan, dan yang terpenting mengajari dan memotivasi anggota lainnya.

4. Menggunakan keterampilan untuk saling membantu. 
Siswa harus didorong dan dibantu untuk mengembangkan dan mempraktikkan rasa saling percaya, mengembangkan sikap kepemimpinan, membuat keputusan, komunikasi, dan mengelola konflik.

5. Proses kelompok.

Anggota tim merumuskan tujuan kelompok, mengevaluasi tujuan secara periodik bersama-sama tim, dan mengidentifikasi peluang agar tim bisa bekerja lebih efektif.

PK bisa dilaksanakan di dalam dan di luar kelas. PK di dalam kelas bisa meliputi: menjawab atau mengajukan pertanyaan, menjelaskan hasil observasi, memecahkan masalah, meringkas bahan kuliah, mengidentifikasi kelemahan, dan brainsatorming. PK di luar kelas meliputi: mengadakan eksperimen atau penelitian mini, menulis laporan, dan menyiapkan penyajian dalam kelas.

\section{PK DALAM PENGAJARAN BAHASA}

Dalam belajar bahasa Indonesia, kelas yang kondusif memegang peranan yang sangat penting. Hal ini terjadi karena kelas yang kondusif bisa membantu siswa menyerap bahan ajar yang sedang disampaikan guru dan mendorong motivasi siswa untuk mengikuti pelajaran dengan baik. Secara umum kondisi lingkungan yang kondusif bisa merupakan bagian dari keadaan kelas yang memang dibutuhkan untuk belajar bahasa. Namun, kondisi lingkungan yang kondusif bukan monopoli kelas bahasa semata.

Hakikatnya, semua pembelajaran di kelas apa pun mata pelajaran yang diajarkan menuntut kondisi lingkungan yang kondusif. Masalahnya ialah, sejauh mana kondisi kondusif itu secara definitif dan secara spesifik berperanan memberikan kontribusi bagi pelajaran tertentu. Karena itu, untuk memperoleh penjelasan yang rinci mengenai lingkungan kondusif tersebut, diperlukan pendalaman dan uraian yang mendalam.

Ada tiga deskriptor yang dianggap bertanggungjawab terhadap kondisi lingkungan yang kondusif. Ketiga hal itu ialah: lingkungan fisik, lingkungan interaksional, dan lingkungan sosial.

\section{Lingkungan Fisik}

Lingkungan fisik kelas yang dimaksudkan meliputi meja, kursi, papan tulis, gambar, rak buku, almari, pusat musik, komputer, tempat bekerja, perpustakaan/tempat membaca atau menulis, tempat meletakkan mainan, display, tempat bermain, tempat bermain drama, dan kotak surat.

Daftar lingkungan fisik tersebut, sebenarnya hal-hal yang sangat umum yang juga bisa disediakan untuk semua kondisi pembelajaran di kelas. Bahkan ada beberapa benda yang tidak mencerminkan lingkungan kelas di sekolah dasar di Indonesia pada umumnya. Benda-benda tersebut antara lain: rak buku, almari, pusat musik, komputer, tempat bermain drama, dan kotak surat. 
Seperti yang kita maklumi, kelas-kelas di Indonesia baik tingkat SD, SLTP maupun SLTA umumnya hanya memiliki satu model. Satu kelas digunakan untuk mengajar semua mata pelajaran tanpa ada perbedaan. Selain itu, kelas di Indonesia sangat tidak lazim disediakan komputer atau tempat bermain drama. Dengan demikian, gambaran yang spesifik mengenai lingkungan fisik tergantung pada kondisi setempat.

Nampaknya yang secara khusus penting diperhatikan ialah aspek penataan ruang dan topografi kelas. Penataan ruang di sekolah yang berstandar nasional dan internasional sangatlah bagus untuk mendorong minat belajar. Misalnya, meja kursi bisa disusun sesuai setting kelas, memutar, setangah lingkaran, atau tidak menggunakan kursi. Selain itu, papan tulis dan alat pendukung papan tulis seperti plano, kertas karton, dan proyektor tersedia dengan baik. Dengan penataan ruang dan topografi kelas seperti ini, belajar menjadi fleksibel dan suasana kondusif untuk mendorong semangat belajar juga terkontrol.

Hakikatnya, kelas-kelas di sekolah-sekolah di Indonesia tidak mendukung untuk gambaran seperti ini. Karena itu, untuk menciptakan suasana kelas yang kondusif dengan ukuran PK yang ideal sulit dilaksanakan. Yang bisa dilakukan ialah membuat setting pengelolaan kelas yang optimal sesuai konteksnya. Untuk itu, pengelolaan kelas perlu diarahkan pada situasi kelas yang kontekstual, tidak terlalu kaku, dan mengacu pada prinsip-prinsip pembelajaran kelompok.

Namun, efektifitas pengelolaan kelas walaupun sudah disesuaikan dengan kondisi PK masih akan terhambat oleh kemampuan guru. Berbagai penelitian menunjukkan bahwa guru memiliki kelemahan mendasar dalam mengelola dan mengembangkan kelas karena keterbatasan penataan ruang dan pengetahuan mengenai model-model pembelajaran di kelas. Data empiris mengenai jumlah siswa yang berkisar antara 40 orang merupakan satu hal yang persifat permanen dan tidak mudah untuk diubah. Dorongan agar guru membuat inovasi pengajaran, misalnya menggunakan materi selain dari buku teks juga merupakan kendala yang rumit diatasi. Akhirnya, untuk mengubah situasi kelas dari sikap duduk saja, guru memerlukan keberanian dan contoh yang berani dari orang lain. Sekali lagi, situasi kelas yang kondusif akhirnya sulit tercapai, jika ukuran yang digunakan kriteria PK yang ideal.

Dalam pembelajaran bahasa, kelas kecil berjumlah antara 20 siswa merupakan kelas yang ideal. Jumlah ini jarang diperhatikan oleh guru di Indonesia karena faktor kebijakan. Misalnya, kepala sekolah mengharuskan kelas diisi 30 orang, dan guru tidak bisa menolak kebijakan tersebut. Dari segi tempat duduk, kursi dan meja mestinya bisa dibuat secara fleksibel untuk diubah-ubah menurut formasi lingkaran, setengah lingkaran, atau berjajar muka-belakang. Masalahnya ialah meja dan kursi belajar siswa di sekolahsekolah Indonesia dibuat menjadi satu dan tidak bisa dipindah-pindahkan. Hal 
ini menyebabkan management kelas sulit diubah-ubah sesuai dengan kondisi ideal yang diharapkan guru.

Kelas bahasa menuntut kondisi yang fleksibel tersebut. Sementara itu, kelas tidak memungkinkan untuk dimodifikasi sesuai kehendak guru. Selain itu, media pendukung seperti poster, gambar, dan buku-buku di kelas-kelas Indonesia dirancang untuk kebutuhan semua mata pelajaran. Untuk kelas bahasa, media pendukung tersebut bisa lebih difokuskan misalnya gambar yang isinya menguraikan kosa kata, pengembangan ide untuk mengarang, atau menceritakan suatu keadaan.

\section{Lingkungan Interaksional}

Secara umum, lingkungan interaksional mengacu pada teori interaksi di kelas terutama dalam memberi motivasi siswa. Lingkungan interaksional haruslah dimulai dari keadaan ketika guru dan siswa berinteraksi dalam proses belajar mengajar. Berdasarkan model interaksi di kelas inilah, selanjutnya bisa dikembangkan ciri-ciri bagaimana kelas bahasa yang kondusif. Uraian bisa dimulai dari "syarat-syarat wajib" bagi guru dalam berinteraksi dengan siswa, perangkat trik dan prosedur yang perlu diperhatikan guru, dan penciptaan suatu pola agar siswa terdorong oleh dirinya sendiri dalam mengerjakan kegiatan berbahasa, seperti menyimak, membaca, menulis, dan berbicara. Secara lebih tajam, ciri-ciri interaksi dalam kelas berbicara, kelas membaca, kelas menulis, dan kelas menyimak perlu dipertajam.

Interaksi kelas yang ideal ialah interaktif. Syarat terciptanya interaksi kelas yang interaktif ialah pembelajaran berpusat pada siswa dan siswa aktif berpartisipasi dalam aktivitas kelas. Peran guru ialah fasilitator dan mendorong siswa untuk selalu terlibat pada kegiatan kelas (Baradja, 1985). Namun demikian, tugas menjaga agar kelas aktif dan interaktif tidaklah ringan. Budiharso (2004) mengemukakan bahwa dalam kondisi ini guru harus bisa menjaga "individualized instruction" yang selalu dilakukan untuk setiap siswa. Untuk menjaga agar semua siswa mendapat perhatian yang proporsional, guru harus mampu mengatur irama penjelasan dan menguasai materi yang diajarkan dengan baik. Selain itu, inovasi teknik mengajar dan improvisasi materi baru harus dikuasai dengan cukup matang. Jika hal itu tidak dikuasai oleh guru, kelas interaktif tidak akan dicapai dan pengajaran yang memenuhi kriteria PK akan gagal.

\section{Lingkungan Sosial}

Sebagaimana uraian mengenai lingkungan fisik dan lingkungan interaksional, uraian mengenai lingkungan sosial dalam kelas bahasa sesungguhnya bisa juga direfleksikan untuk mata pelajaran lainnya. Fokus lingkungan sosial terutama pada keadaan siswa dan pada penataan kelas.

Hakekatnya, lingkungan sosial dalam kelas mengacu pada kondisi terciptanya cooperative learning. Kondisi ini dalam kelas bahasa bermanfaat 
untuk mendorong siswa agar bisa bersosialisasi dengan teman sekelas lainnya. Jika ada siswa yang introvert tidak selalu menutup diri. Sedangkan siswa yang ekstrovert tidak cenderung untuk menyombongkan diri atau berperilaku diskriminatif terhadap siswa introvert.

Dalam konteks pembelajaran berbasis kontekstual, lingkungan sosial juga mengacu pada teman sekelas, guru, dan orang-orang lain yang berada di sekitar kelas baik ketika pembelajaran berlangsung maupun ketika di luar kelas. Fungsi lingkungan sosial ialah memberi penyadaran pada siswa bahwa mereka harus saling membantu, saling membutuhkan satu dengan yang lain, berinteraksi, menyampaikan persoalan-persoalan, curhat, dan sebagainya. Kindisi ini perlu ditanamkan pada siswa agar mereka memanfaatkan untuk tujuan pembelajaran. Secara khusus, untuk kelas bahasa, lingkungan sosial bisa memberi exposure yang baik tentang penggunaan kata atau kalimat sesuai dengan lingkungan sosialnya.

\section{PENUTUP}

Kajian dalam kalah ini difokuskan pada kelas bahasa ditinjau dari bagaimana PK bisa dimanfaatkan optimal dalam proses belajar mengajar. Untuk tujuan tersebut, prinsip pengajaran kelompok merupakan hal penting yang harus diperhatikan guru. Namun demikian perlu digaris bawahi bahwa hakikat PK bukanlah sekadar mengumpulkan siswa dalam satu kelompok kemudian diajar menggunakan metode kelompok. Kelompok tersebut haruslah dinamis dan mencerminkan model pengelolaan kelas yang maksimum.

Dalam kaitan ini, peranan guru agar tampil secara percaya diri dan bisa mengembangkan inovasi dan improvisasi materi merupakan syarat penting yang perlu dipersiapkan matang. Fungsi guru yang harus menjada interaksi kelas dengan frekuensi tatap muka dengan setiap siswa untuk memberikan bimbingan dan perhatian secara individu, merupakan keterampilan guru yang harus dilakukan dengan baik.

Salah satu hal penting agar upaya itu tercapai ialah menciptakan kelas yang kondusif. Kelas yang kondusif dirujuk pada kondisi ideal tiga hal: lingkungan fisik kelas, inetaraksi kelas, dan lingkungan sosial. Secara umum, lingkungan fisik kelas-kelas di Indonesia tidaklah menggembirakan. Banyak kendala yang menyebabkan kelas tidak bisa dimaksimalkan sesuai dengan prinsip pengelolaan kelas yang baik. Karena itu, lingkungan fisik kelas ini biarlah berjalan sesuai konteksnya. Lingkungan inetaraksional agak berbeda. Interaksi kelas ini bisa diciptakan dan dilatihkan pada guru. Namun demikian, diperlukan pelatihan yang cukup ketat dan intensif agar interaksi kelas bisa dikerjakan dengan baik oleh guru. Pelatihan ini meliputi pelatihan metode mengajar, pengembangan materi, dan substansi pelajaran. Selanjutnya, lingkungan sosial merupakan media pembelajaran agar siswa tidak mementingkan diri sendiri. Lingkungan sosial juga mengajarkan agar antarsiswa saling membantu, saling menghargai, dan bisa mengambil hikmah 
dari orang lain. Dalam kelas bahasa, lingkungan sosial merupakan exposure untuk mengimplementasikan bahasa seusia dengan kondisi yang senyatanya di lapangan.

Akhirnya, disimpulkan bahwa hakikat PK ialah pembelajaran yang mendorong siswa aktif dan proaktif secara mandiri. Kemandirian itu bisa diciptakan melalui dorongan teman dan lingkungan. Guru merupakan fasilitator yang harus menjaga kondisi kelas. PK bukanlah monopoli mata pelajaran bahasa saja, walaupun beberapa studi menunjukkan bahwa PK memiliki keunggulan-keunggulan penting jika digunakan untuk pengajaran bahasa. Dengan kata lain, kajian ini tidak dimaksudkan semata-mata untuk pembelajaran bahasa Indonesia saja. PK dalam kajian ini ternyata juga cocok untuk pembelajaran mata pelajaran selain bahasa Indonesia dengan potensi keberhasilan yang sama asalkan prinsip-prinsip pengajarannya dilakukan secara konsisten.

\section{DAFTAR BACAAN}

Budiharso, Teguh. 2004a. Prinsip dan Strategi Pengajaran Bahasa. Surabaya: Penerbit Lutfansah Mediatama.

Budiharso, Teguh. 2004b. Cooperative Learning: Critical Review. CERTEL Journal, 1(1):1-6.

Sadtono. E. 1997. The Development of TEFL in Indonesia. Malang: Penerbit IKIP Malang.

Samsuri. 1997. Cooperative Learning. Makalah. Surabaya: Universitas Tujuh Belas Agustus Surabaya.

Departemen Pendidikan Nasional. 2002. Pendekatan Kontekstual

(ContextualTeaching and Learning (CTL)). Jakarta: Dirjen Dikdasmen.

Depdikbud. 1995. Petunjuk Tekniks Mata Pelajaran Bahasa Indonesia. Jakarta.

Joyce, B. dan Weil, M. 1986. Models of Teaching. New Jersey: Prectice-Hall.

Hutawarman, Wawang. 2004. Cooperative Learning, Seameo Recsam-Penang. Makalah disajikan pada pelatihan guru sekolah pelaksana terbatas kurikulum 2004 di Jakarta.

Ibrahim, Muslimin dkk. 2000. Pembelajaran Kooperatif. Surabaya: Universitas Negeri Surabaya University Press

Nur, Mohamad \& Retno W., Prima. 2000. Pengajaran Berpusat Kepada Siswa dan Pendekatan Konstruktivis Dalam Pengajaran. Surabaya: Universitas Negeri Surabaya University Press

Nur, Mohamad. 2001. Pengajaran dan Pembelajaran Kontekstual. Makalah disajikan pada Pelatihan TOT Guru Mata Pelajaran di Pusat Pendidikan dan Pelatihan Wilayah IV Surabaya.

Arends, Richard. 1997. Classroom Intruction and Management. New York: Mc Grow-Hill Companics Inc. 
Dahar, Ratna Willis. 1989. Teori-Teori Belajar. Jakarta: Erlangga.

Ernest. Goetz, Patricia A. Alexander, Michael J. Ash. 1992. Education Psychology A Classroom Perspective. Sydney: New York Oxford.

Hudojo, Herman. 1979. Pengembangan Kurikulum Matematika dan Pelaksanaannya di Depan Kelas. Surabaya: Usaha Nasional.

Hudoyo, Herman. 1989. Mengajar Belajar Matematika. Jakarta: Ditjen Dikti Depdikbud, P2LPTK.

Kauchak, Donald P and Eggen, Paul D. 1996. Learning and Teaching, Research-Based Method, Needham Heihts, New York: Allyn and Bacon Publisher.

Martin, David J. 1994. Concept Mapping As Aid to Lesson Planning: A Longitudinal Study, Journal of Elementary Science Education, 6(2):1130.

Novak, J.D.,\& Gowin, G.B., 1985. Learning How To Learn. New York: Cambridge Universty Press.

Orton, Anthony. 1992. Learning Mathematics Issues, Theory and Classroom Practice. New York: Cambridge University Press.

Slavin, Robert E. 1995. Cooperative Learning: Theory, Research and Pratice. Massachusetts: Allyn and Bacon Publisher. 
CENDEKIA, Vol. 11, No. 1, April 2017

p ISSN: 1978 2098; e ISSN: 2407 8557

Http://cendekia.pusatbahasa.or.id; Email: cendekiaoslo@gmail.com Center of Language and Culture Studies, Surakarta, Indonesia

Armadi, Samsu. 2017. Review Efektifitas Model Cooperative Learning

dalam Pembelajaran Bahasa. Cendekia, (2017), 11(1): 117 128. 